\title{
Yield and quality of aromatic fine rice as affected by variety and nutrient management
}

\author{
S. K. Sarkar ${ }^{*}$, M. A. R. Sarkar, N. Islam and S. K. Paul \\ Department of Agronomy, Bangladesh Agricultural University, Mymensingh-2202, Bangladesh \\ *Email: shubroto.252@gmail.com
}

\begin{abstract}
An experiment was conducted at the Agronomy Field Laboratory, Bangladesh Agricultural University, Mymensingh, to study the yield and quality of aromatic fine rice as affected by variety and nutrient management during the period from June to December 2013. The experiment comprised three aromatic fine rice varieties viz. BRRI dhan34, BRRI dhan37 and BRRI dhan38, and eight nutrient managements viz. control (no manures and fertilizers), recommended dose of inorganic fertilizers, cowdung at $10 \mathrm{t} \mathrm{ha}^{-1}$, poultry manure at $5 \mathrm{t} \mathrm{ha}^{-1}, 50 \%$ of recommended dose of inorganic fertilizers $+50 \%$ cowdung, $50 \%$ of recommended dose of inorganic fertilizers $+50 \%$ poultry manure, $75 \%$ of recommended dose of inorganic fertilizers $+50 \%$ cowdung and $75 \%$ of recommended dose of inorganic fertilizers + $50 \%$ poultry manure. The experiment was laid out in a randomized complete block design with three replications. The tallest plant $(142.7 \mathrm{~cm})$, the highest number of effective tillers hill ${ }^{-1}(10.02)$, number of grains panicle ${ }^{-1}(152.3)$, panicle length $(22.71 \mathrm{~cm}), 1000$-grain weight $(15.55 \mathrm{~g})$ and grain yield $\left(3.71 \mathrm{t} \mathrm{ha}{ }^{-1}\right)$ were recorded in BRRI dhan34. The highest grain protein content (8.17\%) was found in BRRI dhan34 whereas the highest aroma was found in BRRI dhan37 and BRRI dhan38. The highest number of effective tillers hill ${ }^{-1}(11.59)$, number of grains panicle ${ }^{-1}$ (157.6), panicle length $(24.31 \mathrm{~cm})$ and grain yield $\left(3.97 \mathrm{t} \mathrm{ha}^{-1}\right)$ were recorded in the nutrient management of $75 \%$ recommended dose of inorganic fertilizers $+50 \%$ cowdung $\left(5 \mathrm{t} \mathrm{ha} \mathrm{h}^{-1}\right)$. The treatment control (no manures and fertilizers) gave the lowest values for these parameters. The highest grain yield $\left(4.18 \mathrm{t} \mathrm{ha}^{-1}\right)$ was found in BRRI dhan34 combined with $75 \%$ recommended dose of inorganic fertilizers $+50 \%$ cowdung, which was statistically identical to BRRI dhan34 combined with $75 \%$ of recommended dose of inorganic fertilizers + 50\% poultry manure and the lowest grain yield $\left(2.7 \mathrm{t} \mathrm{ha}^{-1}\right)$ was found in BRRI dhan37 in control (no manures and fertilizers). The highest grain protein content $(10.9 \%)$ was obtained in the interaction of BRRI dhan34 with recommended dose of inorganic fertilizers which was as good as that of BRRI dhan38 and $75 \%$ of recommended dose of inorganic fertilizers $+50 \%$ poultry manure. The highest aroma was found in BRRI dhan38 combined with $75 \%$ recommended dose of inorganic fertilizers $+50 \%$ cowdung.
\end{abstract}

Keywords: Nutrient management, Fine rice, Yield, Aroma, Protein content

\section{Introduction}

Rice (Oryza sativa L.) crop is interwoven in the cultural, social and economic lives of millions of Bangladeshis and it holds the key for food and nutritional security of the country. It is consumed as the staple food and has been given the highest priority in meeting the demands of its ever-increasing population in Bangladesh. In recent years, aromatic rice has been introduced to the global market. Aromatic rice has great potential to attract rice consumer for its taste and deliciousness, and high price to boost up the economic condition of the rice grower in the developing countries like Bangladesh. Because of its natural chemical compounds which give it a distinctive scent or aroma when cooked, aromatic rice commands a higher price than non-aromatic rice. In Bangladesh, a number of fine rice cultivars are grown by the farmers. Some of them have special appeal for their aroma. Such common cultivars are Chinisagar, Badshabhog, Kataribhog, Kalizira, Tulsimla, Dulabhog, Basmati, Banglamoti (BRRI dhan50), BRRI dhan34, BRRI dhan37 and BRRI dhan38.

Bangladesh has a bright prospect for export of fine rice thereby earning foreign exchange. The yield of fine rice is lower than that of coarse and medium rice varieties. Although the geographical, climatic and edaphic conditions of Bangladesh are favorable for year-round rice cultivation, the national average of rice yield is rather low $\left(2.92 \mathrm{t} \mathrm{ha}^{-1}\right)$ (BBS, 2012). The reasons for low yield are mainly associated with selection of improved varieties and judicious fertilizer management especially of organic fertilizer like cowdung, poultry manure and/or their integration with inorganic fertilizers. 
In all the agricultural systems there is inevitably a loss of plant nutrients. Nutrient mining, depletion of soil organic matter and reduction in soil aggregates have been identified as reasons of yield stagnation or decline in the productivity of crops (Rahman and Yakupitiyage, 2006). In Bangladesh, nutrient stresses of soils are increasing day by day. Use of fertilizer is an essential component of modern farming with about $50 \%$ of the world crop production (Prodhan, 1992). Among the cultural technologies, integrated nutrient management like application of cowdung, poultry manure along with other inorganic fertilizers and selection of right variety are the important ones in augmenting the yield of crop. The efficient nutrient management increases crop yield and at the same time reduces fertilization cost. Therefore, the present study was undertaken to evaluate the effects of variety and nutrient management on the yield and quality of aromatic fine rice.

\section{Materials and Methods}

The research work was carried out at the Agronomy Field Laboratory, Bangladesh Agricultural University, Mymensingh, during the period from June to December 2013. The experimental site belongs to the Sonatola series of the dark grey floodplain soil type under Old Brahmaputra Floodplain Agro-Ecological Zone (AEZ-9). The field was a medium high land with well drained silty-loam texture having $\mathrm{pH}$ value 6.5 and $1.67 \%$ organic matter content. The experiment was laid out in a two factor randomized complete block design with three replications. The experiment comprised three aromatic fine rice varieties viz. BRRI dhan34, BRRI dhan37 and BRRI dhan38 and eight nutrient managements viz. control (no manures and fertilizers), recommended dose of inorganic fertilizers (i.e 150, 97, 70, 60 and $12 \mathrm{~kg} \mathrm{ha}^{-1}$ urea, TSP, MoP, gypsum and zinc sulphate, respectively), cowdung at $10 \mathrm{t} \mathrm{ha}^{-1}$, poultry manure at $5 \mathrm{t} \mathrm{ha} \mathrm{h}^{-1}, 50 \%$ of recommended dose of inorganic fertilizers $+50 \%$ cowdung, $50 \%$ of recommended dose of inorganic fertilizers $+50 \%$ poultry manure, $75 \%$ of recommended dose of inorganic fertilizers $+50 \%$ cowdung and $75 \%$ of recommended dose of inorganic fertilizers $+50 \%$ poultry manure. Seeds of the aromatic fine rice varieties were collected from the Bangladesh Rice Research Institute, Joydebpur, Gazipur. The nursery beds were puddled with country plough, cleaned and levelled with ladder. Then the sprouted seeds were sown in the nursery beds on 30 June 2013. At the time of final land preparation, respective unit plots were amended with organic and inorganic fertilizers according to treatment specification. Urea was applied in three equal splits at final land preparation, 30 days after transplanting (DAT) and 50 DAT. Full dose of triple super phosphate, muriate of potash, gypsum and zinc sulphate were applied at final land preparation. Thirty-day old seedlings were transplanted on 1 August 2013 with three seedlings hill ${ }^{-1}$. Prior to harvest, five hills plot ${ }^{-1}$ were randomly selected excluding border hills and central $1 \mathrm{~m}^{2}$ area from each unit plot for recording data on yield components and yield. The crop was harvested at full maturity. BRRI dhan34 was harvested on 10 December and BRRI dhan37 and BRRI dhan38 were harvested on 18 December 2013. The harvested crop of central $1 \mathrm{~m}^{2}$ area from each plot was separately bundled, properly tagged and then threshed. The grains were cleaned and sun dried to moisture content of $14 \%$. Finally grain and straw yields plot ${ }^{-1}$ were recorded and converted to $t a^{-1}$. Estimation of protein (\%) in grains was done by Micro-Kjeldahl Method (AOAC, 1984). Aroma of rice was detected by olfactory test following the method developed by Nagaraju et al. (1991). In this method, a panel of five judges estimated the intensity of aroma of the chemical treated rice samples by olfaction and gave a score individually for each sample according to the following Table.

\begin{tabular}{ccc}
\hline Degree of Aroma & Score & Type of Quality \\
\hline+ & 1 & Good \\
++ & 2 & Better \\
+++ & 3 & Best \\
\hline
\end{tabular}

Their scores were averaged to obtain the numerical value of aroma for each treatment. The collected data were analyzed statistically using the "analysis of variance" technique and mean differences were adjudged by Duncan's Multiple Range Test (DMRT) (Gomez and Gomez, 1984) using MSTAT- C computer program. 


\section{Results and Discussion}

\section{Effect of variety}

Variety influenced significantly crop characters, yield contributing characters and yield except harvest index (Table 1). The tallest plant $(142.7 \mathrm{~cm})$, the highest number of effective tillers hill $^{-1}(10.02)$, the highest number of grains panicle ${ }^{-1}(152.3)$, grain yield $\left(3.71 \mathrm{t} \mathrm{ha}^{-1}\right)$, straw yield $\left(5.11 \mathrm{t} \mathrm{ha}^{-1}\right)$ and biological yield $\left(8.83 \mathrm{t} \mathrm{ha}^{-1}\right)$ were recorded in BRRI dhan34. Similar results were found elsewhere (Tyeb et al., 2013 and Islam et al., 2012), who reported that variety exerted variable effect on yield and yield contributing characters of rice. The highest number of effective tillers hill ${ }^{-1}$ and the highest number of grains panicle ${ }^{-1}$ were mainly responsible for the highest grain yield. This confirms the report of Islam et al. (2013), who reported the variable effect of variety on the number of effective tillers hill ${ }^{-1}$. The variation in plant height, number of effective tillers hill ${ }^{-1}$ and number of grains panicle ${ }^{-1}$ among the varieties were probably due to heredity or varietal characters. BRRI dhan34 also gave the lowest number of non-effective tillers hill ${ }^{-1}$ (1.63), sterile spikelets panicle ${ }^{-1}(25.01)$ and 1000-grain weight $(11.26 \mathrm{~g})$. Variety had significant effect on qualitative characters like grain protein content (\%) and aroma. The highest grain protein content (8.18\%) was found in BRRI dhan34 followed by BRRI dhan38 (7.98\%) and the lowest one (7.75 \%) was observed in BRRI dhan37. This result was consistent to Dutta et al.(1998) and Alam (2002) who recorded variable protein percentage among varieties. The highest aroma (1.81) was found in BRRI dhan38, which was similar to that of BRRI dhan37 (1.81). The lowest (1.76) aroma was observed in BRRI dhan34. Dutta et al. (1998) reported that aroma varied among the varieties.Varietal differences regarding grain protein content and aroma might be due to their difference in genetic make-up.

Table 1. Effect of variety on yield and yield contributing characters as well as quality of aromatic fine rice

\begin{tabular}{|c|c|c|c|c|c|c|c|c|c|c|c|c|c|c|}
\hline Treatments & $\begin{array}{l}\text { Plant } \\
\text { height } \\
\text { (cm) }\end{array}$ & $\begin{array}{c}\text { Number } \\
\text { of total } \\
\text { tillers } \\
\text { hill-1 }^{-1}\end{array}$ & $\begin{array}{l}\text { Number of } \\
\text { effective } \\
\text { tillers hill-1 }\end{array}$ & $\begin{array}{c}\text { Number of } \\
\text { non- } \\
\text { effective } \\
\text { tillers hill-1 }\end{array}$ & $\begin{array}{l}\text { Panicle } \\
\text { length } \\
(\mathrm{cm})\end{array}$ & \begin{tabular}{|l|} 
Number \\
of grains \\
panicle \\
\end{tabular} & $\begin{array}{l}\text { Number of } \\
\text { sterile } \\
\text { spikelets } \\
\text { panicle-1 }\end{array}$ & $\begin{array}{c}1000- \\
\text { grain } \\
\text { weight } \\
(\mathrm{g})\end{array}$ & $\begin{array}{l}\text { Grain } \\
\text { yield } \\
\left.\text { ( } \mathrm{tha}^{-1}\right)\end{array}$ & \begin{tabular}{|c} 
Straw \\
yield \\
$\left(\mathrm{t} \mathrm{ha}^{-1}\right)$
\end{tabular} & $\begin{array}{c}\text { Biological } \\
\text { yield } \\
\left(\mathrm{t} \mathrm{ha}^{-1}\right)\end{array}$ & $\begin{array}{c}\text { Harvest } \\
\text { index } \\
(\%)\end{array}$ & $\begin{array}{c}\text { Grain } \\
\text { protein } \\
\text { content } \\
(\%)\end{array}$ & $\begin{array}{c}\text { Aroma } \\
\text { (numerical) }\end{array}$ \\
\hline BRRI dhan34 & $142.7 a$ & $11.44 a$ & $10.02 \mathrm{a}$ & $1.63 \mathrm{c}$ & $22.71 a$ & $152.3 a$ & $25.01 \mathrm{c}$ & $11.26 c$ & $3.71 \mathrm{a}$ & $5.11 \mathrm{a}$ & $8.83 a$ & 42.02 & $8.18 \mathrm{a}$ & $1.76 \mathrm{~b}$ \\
\hline BRRI dhan37 & $121.7 \mathrm{c}$ & $10.60 \mathrm{c}$ & $9.40 c$ & $1.86 a$ & $19.73 c$ & $118.0 \mathrm{c}$ & $31.79 a$ & $14.60 \mathrm{~b}$ & $3.39 \mathrm{c}$ & $4.70 c$ & $8.09 c$ & 41.84 & $7.75 c$ & $1.81 \mathrm{a}$ \\
\hline BRRI dhan38 & $126.2 \mathrm{~b}$ & $10.86 \mathrm{~b}$ & $9.61 b$ & $1.70 \mathrm{~b}$ & $21.78 \mathrm{~b}$ & $126.2 \mathrm{~b}$ & $27.34 \mathrm{~b}$ & $15.55 \mathrm{a}$ & $3.50 \mathrm{~b}$ & 4.86b & $8.36 \mathrm{~b}$ & 41.77 & $7.98 \mathrm{~b}$ & $1.81 \mathrm{a}$ \\
\hline$S \bar{x}$ & 0.838 & 0.072 & 0.037 & 0.017 & 0.180 & 0.829 & 0.237 & 0.138 & 0.017 & 0.027 & 0.039 & 0.203 & 0.068 & 0.018 \\
\hline $\begin{array}{c}\text { Level of } \\
\text { significance }\end{array}$ & ** & ** & ** & ** & ** & ** & ** & ** & ** & *夫 & ** & NS & ** & ** \\
\hline CV (\%) & 3.15 & 3.22 & 1.87 & 4.71 & 4.13 & 3.08 & 4.14 & 4.90 & 2.32 & 2.75 & 2.27 & 2.38 & 4.23 & 2.88 \\
\hline
\end{tabular}

** $=$ Significant at $1 \%$ level of probability

NS = Not-significant

In a column, figures with dissimilar letter differ significantly as per DMRT.

Crop characters, yield and yield contributing characters except 1000-grain weight were significantly influenced by nutrient management (Table 2). The application of $75 \%$ of recommended dose of inorganic fertilizers+ $50 \%$ cowdung showed superiority in terms of the highest plant height $(139.5 \mathrm{~cm})$, number of total tillers hill ${ }^{-1}(13.41)$, number of effective tillers hill ${ }^{-1}(11.59)$, panicle length $(24.31 \mathrm{~cm})$, number of grains panicle $^{-1}$ (157.6), grain yield $\left(3.97 \mathrm{t} \mathrm{ha}^{-1}\right)$, straw yield $\left(5.49 \mathrm{t} \mathrm{ha}^{-1}\right)$ and biological yield $\left(9.47 \mathrm{t} \mathrm{ha}{ }^{-1}\right)$. Probably this treatment provided adequate nutrients to the plants and exhibited the best performance due to absorption of more nutrients, moisture. These results are in agreement with that of Sikdar (2000) and Kabir et al. (2004) who found differences in yield and yield contributing characters due to different levels of nutrient management. Hossain (2008) also reported that Kataribhog and Badshabhog produced yield of 2.30 and 2.12 tons ha $^{-1}$, respectively. The treatment control (no manures and fertilizers) gave the lowest values for the same parameters due to lack of proper nutrient uptake. The lowest number of noneffective tillers hill $^{-1}(1.15)$ was found from the treatment $75 \%$ of recommended dose of inorganic fertilizers $+50 \%$ cowdung. The highest grain protein content $(9.15 \%)$ was found in the treatment of $75 \%$ of recommended dose of inorganic fertilizers $+50 \%$ poultry manure, which was similar $(8.96 \%)$ to that of recommended dose of inorganic fertilizers. This might be due to availability and uptake of adequate nitrogen from the soil. The highest aroma (2.46) was found in the treatment of $75 \%$ of recommended dose of inorganic fertilizers $+50 \%$ cowdung. The lowest (1.00) aroma was observed in the control treatment. These findings are in conformity with the findings of Dutta et al. (1998). 
Table 2. Effect of nutrient management on yield and yield contributing characters as well as quality of aromatic fine rice

\begin{tabular}{|c|c|c|c|c|c|c|c|c|c|c|c|c|c|c|}
\hline Treatments & $\begin{array}{l}\text { Plant } \\
\text { height } \\
(\mathrm{cm})\end{array}$ & $\begin{array}{c}\text { Number of } \\
\text { total tillers } \\
\text { hill }^{-1}\end{array}$ & $\begin{array}{l}\text { Number of } \\
\text { effective } \\
\text { tillers hill-1 }\end{array}$ & $\begin{array}{l}\text { Number of } \\
\text { non- } \\
\text { effective } \\
\text { tillers hill-1 }\end{array}$ & $\begin{array}{c}\text { Panicle } \\
\text { length } \\
(\mathrm{cm})\end{array}$ & $\begin{array}{l}\text { Number } \\
\text { of grains } \\
\text { panicle }{ }^{-1}\end{array}$ & $\begin{array}{l}\text { Number of } \\
\text { sterile } \\
\text { spikelets } \\
\text { panicle-1 }\end{array}$ & $\begin{array}{l}1000- \\
\text { grain } \\
\text { weight } \\
\text { (g) }\end{array}$ & $\begin{array}{c}\text { Grain } \\
\text { yield } \\
\left(\mathrm{t} \mathrm{ha}^{-1}\right)\end{array}$ & $\begin{array}{l}\text { Straw } \\
\text { yield } \\
\left(\mathrm{t} \mathrm{ha} \mathrm{a}^{-1}\right)\end{array}$ & $\begin{array}{c}\text { Biological } \\
\text { yield } \\
\left(\mathrm{t} \mathrm{h} \mathrm{a}^{-1}\right)\end{array}$ & $\begin{array}{c}\text { Harvest } \\
\text { index } \\
(\%)\end{array}$ & $\begin{array}{c}\text { Grain } \\
\text { protein } \\
\text { content } \\
(\%)\end{array}$ & $\begin{array}{c}\text { Aroma } \\
\text { (numerical) }\end{array}$ \\
\hline $\mathrm{T}_{1}$ & $116.6 \mathrm{e}$ & $8.420 \mathrm{f}$ & $8.070 \mathrm{~h}$ & $2.77 \mathrm{a}$ & $17.72 f$ & $112.7 \mathrm{~g}$ & $17.53 \mathrm{~h}$ & 13.56 & $2.87 \mathrm{~g}$ & $4.30 f$ & $7.18 \mathrm{~g}$ & $40.04 d$ & $6.36 f$ & $1.00 \mathrm{~h}$ \\
\hline $\mathrm{T}_{2}$ & $132.7 \mathrm{~b}$ & $12.16 \mathrm{~b}$ & $10.35 \mathrm{c}$ & $1.49 \mathrm{e}$ & $22.82 \mathrm{~b}$ & $139.4 c$ & $31.67 \mathrm{c}$ & 13.79 & $3.80 \mathrm{c}$ & $5.05 c$ & $8.85 \mathrm{c}$ & 42.96ab & $8.96 \mathrm{a}$ & $2.36 \mathrm{~b}$ \\
\hline $\mathrm{T}_{3}$ & $126.3 d$ & $9.633 \mathrm{e}$ & $8.390 \mathrm{~g}$ & $2.11 \mathrm{~b}$ & $19.05 \mathrm{e}$ & $117.1 f$ & $21.50 \mathrm{~g}$ & 13.64 & $3.06 f$ & $4.55 \mathrm{e}$ & $7.61 \mathrm{f}$ & $40.22 d$ & $7.46 \mathrm{~d}$ & $1.93 d$ \\
\hline $\mathrm{T}_{4}$ & $127.8 \mathrm{~cd}$ & $9.823 \mathrm{e}$ & $8.80 f$ & $1.76 \mathrm{c}$ & 20.61d & $122.0 \mathrm{e}$ & $23.72 f$ & 13.67 & $3.31 \mathrm{e}$ & $4.67 \mathrm{e}$ & $7.98 \mathrm{e}$ & $41.46 \mathrm{c}$ & $7.01 \mathrm{e}$ & $1.40 \mathrm{f}$ \\
\hline $\mathrm{T}_{5}$ & 130.2bd & $10.57 \mathrm{~d}$ & $9.15 \mathrm{e}$ & $1.65 d$ & $21.34 \mathrm{~cd}$ & $124.2 \mathrm{e}$ & $26.95 \mathrm{e}$ & 13.70 & $3.64 d$ & $4.84 \mathrm{~d}$ & $8.48 d$ & 42.91ab & $8.42 b$ & $1.33 \mathrm{~g}$ \\
\hline $\mathrm{T}_{6}$ & $131 \mathrm{bc}$ & $11.26 \mathrm{c}$ & $9.96 \mathrm{~d}$ & $1.56 \mathrm{e}$ & $21.94 \mathrm{c}$ & $132.4 d$ & $29.75 d$ & 13.74 & $3.73 c$ & $4.88 \mathrm{~d}$ & $8.61 d$ & $43.30 \mathrm{a}$ & $8.51 \mathrm{~b}$ & $1.65 \mathrm{e}$ \\
\hline $\mathrm{T}_{7}$ & $139.5 \mathrm{a}$ & $13.41 \mathrm{a}$ & $11.59 a$ & $1.15 \mathrm{~g}$ & 24.31a & $157.6 \mathrm{a}$ & $39.40 \mathrm{a}$ & 14.45 & $3.97 a$ & $5.49 a$ & $9.47 a$ & $42.01 b c$ & $7.88 \mathrm{c}$ & $2.46 \mathrm{a}$ \\
\hline $\mathrm{T}_{8}$ & $137.6 \mathrm{a}$ & $12.46 \mathrm{~b}$ & $11.10 \mathrm{~b}$ & $1.37 f$ & $23.47 \mathrm{~b}$ & $151.7 \mathrm{~b}$ & $33.87 b$ & 13.86 & $3.89 \mathrm{~b}$ & $5.35 b$ & $9.24 b$ & $42.10 \mathrm{bc}$ & $9.15 \mathrm{a}$ & $2.21 \mathrm{c}$ \\
\hline$S \bar{x}$ & 1.36 & 0.117 & 0.060 & 0.028 & 0.294 & 1.35 & 0.387 & 0.225 & 0.028 & 0.045 & 0.064 & 0.333 & 0.112 & 0.018 \\
\hline $\begin{array}{l}\text { Level of } \\
\text { significance } \\
\end{array}$ & ** & ** & $*$ & $* *$ & $* *$ & ** & $* *$ & NS & $* *$ & $* *$ & $* *$ & ** & $* *$ & ** \\
\hline CV (\%) & 3.15 & 3.22 & 1.87 & 4.71 & 4.13 & 3.08 & 4.14 & 4.90 & 2.32 & 2.75 & 2.27 & 2.38 & 4.23 & 2.88 \\
\hline
\end{tabular}

** =Significant at $1 \%$ level of probability

NS = Not-significant

In a column, figures with dissimilar letter differ significantly as per DMRT.

$\mathrm{T}_{1}=$ control (no manures and fertilizers), $\mathrm{T}_{2}=$ recommended dose of inorganic fertilizers (i.e 150,97, 70,60 and $12 \mathrm{~kg}$ Urea, TSP, MoP, Gypsum and $\mathrm{Zn}$ respectively ha $\mathrm{h}^{-1}, \mathrm{~T}_{3}=$ cowdung at $10 \mathrm{t} \mathrm{ha}^{-1}, \mathrm{~T}_{4}=$ poultry manure at $5 \mathrm{t} \mathrm{ha}^{-1}, \mathrm{~T}_{5}=50 \%$ of recommended dose of inorganic fertilizers $+50 \%$ cowdung, $\mathrm{T}_{6}=50 \%$ of recommended dose of inorganic fertilizers $+50 \%$ poultry manure, $\mathrm{T}_{7}=75 \%$ of recommended dose of inorganic fertilizers $+50 \%$ cowdung, T8 $=75 \%$ of recommended dose of inorganic fertilizers $+50 \%$ poultry manure.

\section{Effect of interaction of variety and nutrient management}

The interaction effect of variety and nutrient management was significant on yield and yield components of aromatic fine rice (Table 3). The highest plant height $(149.9 \mathrm{~cm})$, number of total tillers hill $^{-1}(14.23)$, number of effective tillers hill ${ }^{-1}(12.03)$, panicle length $(25.60 \mathrm{~cm})$, number of grains panicle ${ }^{-1}(173)$, grain yield $\left(4.18 \mathrm{t} \mathrm{ha}^{-1}\right)$, straw yield $\left(5.88 \mathrm{t} \mathrm{ha}^{-1}\right)$ and biological yield $\left(10.07 \mathrm{t} \mathrm{ha}^{-1}\right)$ were recorded in the interaction between BRRI dhan34 and $75 \%$ of recommended dose of inorganic fertilizers $+50 \%$ cowdung. The lowest values of these parameters were found in the interaction between BRRI dhan37 and control (no manures and fertilizers). But harvest index (44.06\%) was found maximum in the interaction between BRRI dhan34 and $50 \%$ of recommended dose of inorganic fertilizers $+50 \%$ cowdung. Interaction of BRRI dhan34 with recommended dose of inorganic fertilizers produced the highest grain protein content (10.90\%) which was as good as (10.87\%) BRRI dhan38 with $75 \%$ of recommended dose of inorganic fertilizers $+50 \%$ poultry manure. The lowest grain protein content (6.28\%) was observed in interaction of BRRI dhan37 $\times$ control, which was similar to that of BRRI dhan38 $\times$ control (6.34\%), BRRI dhan37 $\times$ poultry manure at $5 \mathrm{t} \mathrm{ha}^{-1}(6.38 \%)$ and BRRI dhan34 $\times$ control $(6.46 \%)$. The highest aroma (2.61) was found in BRRI dhan38 with $75 \%$ of recommended dose of inorganic fertilizers $+50 \%$ cowdung, which was similar to that of BRRI dhan38 $\times$ recommended dose of inorganic fertilizers. The lowest aroma was found in BRRI dhan34 $\times$ control (1.00) which was similar to aroma from the interactions of BRRI dhan37 $\times$ control (1.00), and BRRI dhan38 $\times$ control (1.00). 
Table 3. Effect of interaction of variety and nutrient management on yield and yield contributing characters of aromatic fine rice

\begin{tabular}{|c|c|c|c|c|c|c|c|c|c|c|c|c|c|c|}
\hline $\begin{array}{l}\text { Interaction } \\
(\mathrm{V} \times \mathrm{N})\end{array}$ & $\begin{array}{c}\text { Plant } \\
\text { height } \\
(\mathrm{cm})\end{array}$ & $\begin{array}{c}\text { Number of } \\
\text { total tillers } \\
\text { hill-1 }^{-1}\end{array}$ & $\begin{array}{l}\text { Number of } \\
\text { effective } \\
\text { tillers hill-1 }\end{array}$ & $\begin{array}{c}\text { Number of } \\
\text { non- } \\
\text { effective } \\
\text { tillers hill-1 }\end{array}$ & $\begin{array}{c}\text { Panicle } \\
\text { length } \\
(\mathrm{cm})\end{array}$ & $\begin{array}{c}\text { Number of } \\
\text { grains } \\
\text { panicle }{ }^{-1}\end{array}$ & $\begin{array}{l}\text { Number of } \\
\text { sterile } \\
\text { spikelets } \\
\text { panicle-1 }\end{array}$ & $\begin{array}{l}1000- \\
\text { grain } \\
\text { weight } \\
\text { (g) }\end{array}$ & $\begin{array}{c}\text { Grain } \\
\text { yield } \\
\left(\mathrm{t} \mathrm{ha}^{-1)}\right.\end{array}$ & $\begin{array}{c}\text { Straw } \\
\text { yield } \\
\left(\mathrm{t} \mathrm{ha}^{-1}\right)\end{array}$ & $\begin{array}{c}\text { Biological } \\
\text { yield } \\
\left(\mathrm{t} \mathrm{ha}^{-1}\right)\end{array}$ & $\begin{array}{c}\text { Harvest } \\
\text { index (\%) }\end{array}$ & $\begin{array}{c}\text { Grain } \\
\text { protein } \\
\text { content } \\
(\%)\end{array}$ & $\begin{array}{c}\text { Aroma } \\
\text { (numerical) }\end{array}$ \\
\hline $\mathrm{V}_{1} \times \mathrm{T}_{2}$ & 148.1ab & $12.90 \mathrm{bc}$ & $10.43 d$ & 1.43hij & $24.23 a b c$ & $169.1 \mathrm{a}$ & $28.81 \mathrm{fg}$ & 11.30 & $3.92 \mathrm{C}$ & $5.30 \mathrm{c}$ & $9.22 \mathrm{~cd}$ & 42.50abcde & $10.90 \mathrm{a}$ & $2.11 \mathrm{e}$ \\
\hline $\mathrm{V}_{1} \times \mathrm{T}_{3}$ & \begin{tabular}{|l|} 
140.1cde \\
\end{tabular} & 9.80hi & $8.83 \mathrm{~h}$ & $2.07 d$ & 20.13hij & $133.6 \mathrm{fg}$ & $19.74 \mathrm{k}$ & 11.16 & $3.22 \mathrm{jk}$ & $4.75 d$ & 7.97jk & $40.39 f g$ & $7.33 \mathrm{e}$ & 1.72gh \\
\hline $\mathrm{V}_{1} \times \mathrm{T}_{4}$ & $141.9 \mathrm{bcd}$ & 10.00ghi & $9.23 \mathrm{~g}$ & $1.70 \mathrm{fg}$ & 22.28defg & $139.9 \mathrm{ef}$ & $22.87 i j$ & 11.21 & 3.37hi & $4.80 \mathrm{~d}$ & $8.17 i j$ & 41.23def & $7.32 \mathrm{e}$ & $1.27 \mathrm{k}$ \\
\hline $\mathrm{V}_{1} \times \mathrm{T}_{5}$ & 145abcd & $10.83 f$ & $9.47 f g$ & $1.53 \mathrm{~h}$ & 23.13cde & $140.7 e$ & 23.99hij & 11.23 & $3.88 \mathrm{~cd}$ & $4.94 d$ & 8.82efg & 43.99ab & $9.01 b c$ & $1.55 \mathrm{j}$ \\
\hline $\mathrm{V}_{1} \times \mathrm{T}_{6}$ & 145.8abc & $11.83 \mathrm{e}$ & $10.33 d$ & 1.47hi & 23.31cde & $157.8 \mathrm{~b}$ & $25.34 \mathrm{~h}$ & 11.29 & $3.90 c$ & $4.95 d$ & 8.85efg & $44.06 \mathrm{a}$ & $9.04 b$ & $1.77 \mathrm{~g}$ \\
\hline $\mathrm{V}_{1} \times \mathrm{T}_{7}$ & $149.9 a$ & $14.23 a$ & $12.03 a$ & $1.03 \mathrm{k}$ & $25.60 a$ & $173.0 \mathrm{a}$ & $32.89 \mathrm{e}$ & 11.43 & $4.18 \mathrm{a}$ & $5.88 a$ & $10.07 a$ & 41.56cdef & $7.33 \mathrm{e}$ & $2.44 b$ \\
\hline $\mathrm{V}_{1} \times \mathrm{T}_{8}$ & $149.7 a$ & $13.37 \mathrm{~b}$ & $11.53 \mathrm{~b}$ & $1.30 \mathrm{j}$ & $25.07 a b$ & $172.2 \mathrm{a}$ & $29.95 f$ & 11.37 & $4.07 a b$ & $5.60 \mathrm{~b}$ & $9.67 \mathrm{~b}$ & 42.06bcdef & $8.00 \mathrm{~d}$ & $2.27 \mathrm{~cd}$ \\
\hline $\mathrm{V}_{2} \times \mathrm{T}_{1}$ & 110.11 & $8.13 \mathrm{j}$ & $7.97 \mathrm{k}$ & $3.03 a$ & $17.47 \mathrm{~m}$ & $97.54 n$ & $18.68 \mathrm{kl}$ & 14.28 & $2.70 \mathrm{~m}$ & $3.83 f$ & 6.530 & 41.34def & $6.28 \mathrm{~g}$ & $1.00 \mathrm{~m}$ \\
\hline $\mathrm{V}_{2} \times \mathrm{T}_{2}$ & \begin{tabular}{|l|} 
123.7hijk \\
\end{tabular} & $11.77 \mathrm{e}$ & 10.23de & $1.57 \mathrm{gh}$ & 20.60hij & 123.6ij & $36.00 \mathrm{~cd}$ & 14.61 & 3.70ef & $4.90 \mathrm{~d}$ & $8.60 \mathrm{gh}$ & 43.02abcd & $8.99 b c$ & $2.43 b$ \\
\hline $\mathrm{V}_{2} \times \mathrm{T}_{3}$ & $116.7 \mathrm{kl}$ & $9.50 \mathrm{i}$ & $8.17 \mathrm{k}$ & $2.20 \mathrm{~d}$ & $18.03 \mathrm{~lm}$ & $101.6 n$ & $22.87 i j$ & 14.34 & 2.891 & $4.44 \mathrm{e}$ & $7.33 \mathrm{mn}$ & $39.40 \mathrm{gh}$ & $8.04 d$ & 2.20de \\
\hline $\mathrm{V}_{2} \times \mathrm{T}_{4}$ & $118.1 \mathrm{k}$ & $9.67 i$ & $8.50 \mathrm{ij}$ & $1.87 \mathrm{e}$ & $18.4 \mathrm{klm}$ & $109.7 \mathrm{~lm}$ & 24.86hi & 14.38 & $3.23 i j$ & $4.49 \mathrm{e}$ & $7.72 \mathrm{kl}$ & 41.86cdef & $6.38 \mathrm{~g}$ & 1.66hi \\
\hline $\mathrm{V}_{2} \times \mathrm{T}_{5}$ & $121.6 \mathrm{jk}$ & $10.4 \mathrm{fgh}$ & 8.73hi & 1.73ef & $19.17 \mathrm{jkl}$ & $114.6 \mathrm{~lm}$ & $32.52 \mathrm{e}$ & 14.44 & 3.47gh & $4.76 \mathrm{~d}$ & $8.23 i j$ & 42.16abcdef & $7.99 \mathrm{~d}$ & $1.160 \mid$ \\
\hline $\mathrm{V}_{2} \times \mathrm{T}_{6}$ & $122.7 \mathrm{ijk}$ & $10.93 f$ & $9.60 f$ & 1.73ef & 19.70ijk & 117.0jkl & 35.98cd & 14.50 & $3.62 f$ & $4.78 d$ & 8.40hi & 43.08abcd & 8.41cd & 1.61ij \\
\hline $\mathrm{V}_{2} \times \mathrm{T}_{7}$ & 130.8fgh & $12.53 \mathrm{~cd}$ & $11.23 b$ & $1.37 \mathrm{ij}$ & 23.23cde & 146.1de & $46.24 a$ & 15.56 & 3.80cde & $5.25 \mathrm{c}$ & 9.05cdef & 41.99cdef & $7.32 \mathrm{e}$ & $2.33 c$ \\
\hline $\mathrm{V}_{2} \times \mathrm{T}_{8}$ & \begin{tabular}{|l|} 
130.0ghi \\
\end{tabular} & $11.83 \mathrm{e}$ & $10.83 c$ & 1.45hij & 21.27fghi & $133.4 \mathrm{fg}$ & $37.15 \mathrm{c}$ & 14.68 & 3.73def & $5.190 \mathrm{c}$ & 8.92defg & 41.82cdef & $8.59 \mathrm{bcd}$ & $2.11 \mathrm{e}$ \\
\hline $\mathrm{V}_{3} \times \mathrm{T}_{1}$ & $118.9 \mathrm{jk}$ & $8.53 \mathrm{j}$ & $7.97 \mathrm{k}$ & $2.73 b$ & $17.77 \mathrm{Im}$ & $109.0 \mathrm{~m}$ & $17.40 \mathrm{~lm}$ & 15.34 & $2.720 \mathrm{~m}$ & $4.36 \mathrm{e}$ & $7.08 n$ & $38.41 \mathrm{~h}$ & $6.34 \mathrm{~g}$ & $1.00 \mathrm{~m}$ \\
\hline $\mathrm{V}_{3} \times \mathrm{T}_{2}$ & \begin{tabular}{|l|}
$126.3 \mathrm{ghij}$ \\
\end{tabular} & $11.80 \mathrm{e}$ & $10.4 d$ & 1.47hi & 23.63bcd & 125.3hi & $30.20 f$ & 15.45 & 3.80cde & $4.96 \mathrm{~d}$ & $8.75 f g$ & $43.36 a b c$ & $6.99 \mathrm{ef}$ & $2.55 a$ \\
\hline $\mathrm{V}_{3} \times \mathrm{T}_{3}$ & 122.0jk & $9.60 \mathrm{i}$ & $8.17 \mathrm{k}$ & $2.07 d$ & 19.0jklm & $116.0 \mathrm{klm}$ & $21.89 \mathrm{j}$ & 15.43 & $3.08 \mathrm{k}$ & $4.46 \mathrm{e}$ & $7.54 \mathrm{~lm}$ & 40.86efg & 7.01ef & $1.88 \mathrm{f}$ \\
\hline $\mathrm{V}_{3} \times \mathrm{T}_{4}$ & 123.5hijk & 9.80hi & $8.67 \mathrm{hi}$ & $1.73 f$ & 21.16ghi & $116.4 \mathrm{jk} / \mathrm{m}$ & 23.43hij & 15.43 & 3.33hij & $4.74 d$ & $8.07 i j$ & 41.29def & $7.32 \mathrm{e}$ & $1.28 \mathrm{k}$ \\
\hline $\mathrm{V}_{3} \times \mathrm{T}_{5}$ & \begin{tabular}{|l|} 
124.1hijk \\
\end{tabular} & $10.47 \mathrm{fg}$ & $9.27 \mathrm{~g}$ & $1.70 \mathrm{fg}$ & 21.72efgh & 117.2jkl & 24.33hi & 15.44 & $3.58 \mathrm{fg}$ & $4.83 \mathrm{~d}$ & 8.41hi & 42.59abcde & $8.24 d$ & $1.28 \mathrm{k}$ \\
\hline $\mathrm{V}_{3} \times \mathrm{T}_{6}$ & \begin{tabular}{|l|} 
124.3hijk \\
\end{tabular} & $11.03 f$ & $9.97 \mathrm{e}$ & 1.5hi & 22.80cdef & 122.3ijk & $27.92 \mathrm{~g}$ & 15.44 & $3.67 \mathrm{ef}$ & $4.91 \mathrm{~d}$ & $8.58 \mathrm{gh}$ & 42.76abcde & $8.06 \mathrm{~d}$ & $1.59 \mathrm{ij}$ \\
\hline $\mathrm{V}_{3} \times \mathrm{T}_{7}$ & \begin{tabular}{|l|} 
137.7def \\
\end{tabular} & $13.47 \mathrm{~b}$ & $11.5 b$ & $1.07 \mathrm{k}$ & 24.10abc & 153.6bc & $39.08 b$ & 16.35 & $3.95 b c$ & $5.35 c$ & $9.30 \mathrm{c}$ & 42.47abcde & $8.99 b c$ & $2.61 a$ \\
\hline $\mathrm{V}_{3} \times \mathrm{T}_{8}$ & \begin{tabular}{|l|} 
133.1efg \\
\end{tabular} & 12.1 & $10.93 c$ & $1.37 \mathrm{ij}$ & 24.07abc & $149.4 \mathrm{~cd}$ & 34.50de & 15.53 & $3.88 \mathrm{~cd}$ & $5.27 \mathrm{c}$ & 9.15cde & 42.43abcde & $10.87 a$ & $2.27 \mathrm{~cd}$ \\
\hline$S \bar{x}$ & 2.37 & 0.204 & 0.105 & 0.048 & 0.051 & 2.35 & 0.670 & 0.390 & 0.048 & 0.077 & 0.111 & 0.576 & 0.194 & 0.031 \\
\hline $\begin{array}{c}\begin{array}{c}\text { Level of } \\
\text { significance }\end{array} \\
\end{array}$ & * & * & * & * & * & ** & ** & NS & ** & ** & ** & * & ** & ** \\
\hline CV (\%) & 3.15 & 3.22 & 1.87 & 4.71 & 4.13 & 3.08 & 4.14 & 4.90 & 2.32 & 2.75 & 2.27 & 2.38 & 4.23 & 2.88 \\
\hline
\end{tabular}

In a column, figures with dissimilar letter differ siọnifirantly ac nor חMMRT

$\begin{array}{ll}* * \text { =Significant at } 1 \% \text { level of probability. } & \mathrm{V}_{1}=\text { BRRI dhan34 } \\ * \text { =Significant at 5\% level of probability. } & \mathrm{V}_{2}=\text { BRRI dhan37 } \\ \text { NS= Not-significant } & \mathrm{V}_{3}=\text { BRRI dhan38 }\end{array}$

$\mathrm{T}_{1}=$ control (no manures and fertilizers), $\mathrm{T}_{2}=$ recommended dose of inorganic fertilizers (i.e 150,97, 70,60 and $12 \mathrm{~kg}$ Urea, TSP, MoP, Gypsum and $\mathrm{Zn}$ respectively ha $\mathrm{h}^{-1}, \mathrm{~T}_{3}=$ cowdung at $10 \mathrm{t} \mathrm{ha}^{-1}, \mathrm{~T}_{4}=$ poultry manure at $5 \mathrm{t} \mathrm{ha} \mathrm{a}^{-1}, \mathrm{~T}_{5}=50 \%$ of recommended dose of inorganic fertilizers $+50 \%$ cowdung, $\mathrm{T}_{6}=50 \%$ of recommended dose of inorganic fertilizers $+50 \%$ poultry manure, $\mathrm{T}_{7}=75 \%$ of recommended dose of inorganic fertilizers $+50 \%$ cowdung, T8 $=75 \%$ of recommended dose of inorganic fertilizers $+50 \%$ poultry manure

\section{Conclusion}

From the present study, it can be concluded that aromatic fine rice cv.BRRI dhan34 combined with $75 \%$ of recommended dose of inorganic fertilizers $+50 \%$ cowdung performed better in terms of yield components and yield. On the other hand, grain protein content was higher in BRRI dhan34 with recommended dose of inorganic fertilizers and better aroma was found in BRRI dhan38 with $75 \%$ of recommended dose of inorganic fertilizers $+50 \%$ cowdung.

\section{References}

Alam, B.M.R. 2002. Effect of different levels of urea super granules on the growth and yield of three varieties of boro rice. MS(Ag.) Thesis, Dept. Agron., Bangladesh Agril. University, Mymensingh. 111 p.

AOAC. 1984. Official Methods of Analysis. Association of Official Agricultural Chemists. Washington, D.C. pp. 121-135.

BBS (Bangladesh Bureau of Statistics). 2012. The Yearbook of Agricultural Statistics of Bangladesh. Bangladesh Bur. Stat., Stat. Div., Minis. Plan., Govt. Peoples Repub., Bangladesh, Dhaka.pp.136-140.

Dutta, R.K., Lahiri, B.P. and Mia, M.A.D. 1998. Characterization of some aromatic rice cultivars in relation to their physio-chemical quality of grains. Indian J. Plant Physiol. 3(1): 61-64.

Gomez, K.A, and Gomez, A.A. 1984. Statistical Procedures for Agricultural Research. Int. Rice Res. Inst., John Wiley and Sons. New York, Chichester, Brisbane, Toronto, Singapore. 680p. 
Hossain, M.F. 2008. Improving the yield and quality of aromatic rice through manipulation of cultural practices. Ph.D. dissertation. Bangladesh Agricultural University (BAU), Mymensingh, Bangladesh, pp. 126-130.

Islam, N., Kabir, M.Y., Adhikary, S.K. and Jahan, M.S. 2013. Yield Performance of Six Local Aromatic Rice Cultivars. IOSR Journal of Agriculture and Veterinary Science. Volume 6, Issue 3 (Nov. - Dec. 2013), pp 58-62.

Islam, M.S., Sarkar, M.A.R., Uddin, S. and Parvin, S. 2012. Yield of Fine Rice Varieties as Influenced by Integrated Management of Poultry Manure, Urea Super Granules and Prilled Urea. J. Environ. Sci. \& Natural Resources, 5(1): 129 - 132.

Kabir, M.E., Kabir, M.R. Jahan, M.S. and Das, G.G. 2004. Yield performance of three aromatic fine rice in a coastal medium high land. Asian Journal of Plant Science, 3(5): 561-563.

Nagaraju, M., Mohanty, K.K., Chowdhury D. and Gangadharan, C. 1991. A simple technique to detect scent in rice. Oryza, 28: 109110.

Prodhan, S.B. 1992. Status of fertilizer use in developing countries of Asia and Pacific region. Proc. Regi. FADINAP Seminar, Chiang Mai, Thailand. pp 37-47.

Rahman, M.M. and Yakupitiyage, A. 2006. Use of fishpond sediment for sustainable aquaculture-agriculture farming. International Journal of Sustainable Development and Planning, 1: 192-202.

Sikdar, M.S.I. 2000. Effect of spacing and nitrogen fertilizer level on the yield and quality of some varieties of aromatic rice.M. Sc. Dissertation. Bangladesh Agricultural University, Bangladesh, pp. 1- 126.

Tyeb, A., Paul, S.K. and Samad, M.A. 2013. Performance of variety and spacing on the yield and yield contributing characters of transplanted aman rice. J. Agrofor. Environ. 40(4): 595-597. 